\title{
Does Artificial Intelligence (AI) Enabled Recruitment Improve Employer Branding?
}

\author{
Giulia Baratelli ${ }^{1} \&$ Elanor Colleoni ${ }^{1}$ \\ ${ }^{1}$ Department of Business, Law, Economics and Consumption, IULM University, Milan, Italy \\ Correspondence: Elanor Colleoni, Department of Business, Law and Economics and Consumption, IULM \\ University, Milan, Italy. E-mail: Elanor.colleoni@iulm.it
}

Received: November 22, 2021

Accepted: December 24, 2021

Online Published: January 13, 2022

doi:10.5539/ijbm.v17n2p45

URL: https://doi.org/10.5539/ijbm.v17n2p45

\begin{abstract}
Extant research over the last decades has stressed how artificial intelligence (AI) can be used to boost the recruitment process and to attract the best talents. Although AI is increasingly used for talent acquisition, with $36 \%$ of hiring processes expected to have a pre-screen through AI (Oracle, 2019) in the next two years, we have limited knowledge of how AI shapes talents' perceptions about the organisation to which they are applying to. The goal of this research is to investigate if and how the usage of AI in the recruitment process improves employer attractiveness and employer branding in the eyes of the applicants. To investigate this issue a survey has been conducted on a random sample of individuals composed of $50 \%$ females and $50 \%$ males. To examine the survey's result a structural equation modeling (SEM) has been applied. Results showed a positive relationship between EB and AI and more in particular that AI-enabled tools are perceived in a positive way by potential candidates. Thus, according to this study, AI is significantly related to Employer branding and therefore it contributes to improving talent attraction.
\end{abstract}

Keywords: Artificial intelligence, employer branding, AI-enabled recruitment, employer attractiveness

\section{Introduction}

Organizations operating in the contemporary competitive environment derive much of their wealth from intellectual capital (IC) (Kaplan and Norton, 2004). In this context, the real competitive advantage lies in the quality of the people the company employs (Beechler and Woodward, 2009). As a result, the ability to attract and retain the best talents have become one of the key goals for organizations (Chambers et al., 1998). The role and relevance of onboarding the best employees and keeping them aligned is also emphasized by current theories of customer centricity which stress how employees are key to successfully engaging with customers and therefore to implement the customer centricity paradigm within the organization (Colleoni et al., 2021). In order to attract the best employees, companies increasingly implement sophisticated targeted communication and marketing actions, engaging in a process of Employer Branding (EB) with the goal of building an attractive image for its current and future employees.

The employer branding process is anchored on the belief that an effective branding of an organisation as an attractive employer, can give a company an advantage in the "war for talent" by attracting and retaining a talented workforce (Sutherland et al. 2002). Against the backdrop of the ascending role of human capital, the technological context of how companies recruit people has also changed. Currently, companies are experiencing a great transformation in their recruitment practices thanks to the introduction of artificial intelligence (AI) tools in recruiting related activities. Based on Oracle's (2019) research, over a third (36\%) of HR professionals say they expect high utilization of AI in the next two years and $61 \%$ of the respondents expect at least moderate utilization within a year (Oracle, 2019). Therefore, in the future HR professionals will need to become more knowledgeable in this area as more recruitment-related products and services will incorporate AI into them. It is therefore crucial to understand how to use AI at best to ensure the best selection of talents.

The majority of the research already conducted on recruiting and selection through AI techniques focused largely on the reliability and validity of recruitment and selection process, activities and techniques (Van Esch et al., 2021). Surprisingly, little research has been conducted on how AI shapes job candidates' perceptions of the organisation using AI in the selection process. Given the importance of candidate reactions to recruiting techniques, the little number of empirical studies focusing on the topic (Van Esch, Black, Franklin, \& Harder, 
2020), and the spread of the use of AI-enabled tools in recruiting, it seems that a study of candidate perception and reaction on AI-enabled recruiting could make worthwhile contributions to both research and practice (Van Esch, P., Black, J. S., \& Ferolie, J., 2019). Therefore, aiming to start filling the gap, this study assesses how the perception of AI systems held by potential employees influences the perceived employee brand attractiveness and, as a consequence, the candidates' intention to submit a job application to the organisation.

The paper is structured as follows. In the first part of the paper, we review the literature on employer branding, employer attractiveness, and AI-enabled recruitment. In particular, in the first paragraph, we review the state-of-the-art of employer branding debate, and outline the current employer branding framework. In the second paragraph, we introduce the state-of-the art debate on Artificial intelligence usage for recruitment, outline open points, and formulate the hypothesis at the heart of the study. Based on the hypothesis formulated, we present an updated framework for employer branding that also includes AI-enabled recruitment. In the second part, we present the data collected, the variables used in the analysis and the analytical procedure applied in order to test the relevance and impact of AI-enabled recruitment in the employer branding process. In the third section, we present the results of our statistical model and conclude drawing implications of our findings for the employer branding studies.

\section{Theoretical Framework}

\subsection{Competing for Attracting Talents}

High-quality employees are critical to the firm's competitiveness in the global economy. As extensive research has shown, the ability of companies to attract and retain talents is crucial for a firm success (Chambers et al., 1998) because of the transition from the industrial age (product-based) to the information age (knowledge-based), in which companies derive much of their value from the management and manipulation of knowledge, rather than raw material (Johnson et al., 2005). However, while in the past it has been relatively easy to find resources for companies, radical changes in the labor market structure in recent years have caused companies to be involved in what McKinsey called a "war" for the acquisition of talent to survive growing global competition (Michaels et al., 2001). As a consequence, businesses face tough times and need strategies to maintain their position as companies highly valued by potential and existing employees (Lievens \& Highhouse, 2003). To attract and retain talents, traditional working benefits, such as high salaries and prestigious positions are relevant but not always defining (Gray \& Balmer, 1998). Instead, current research has shown how talents increasingly search for incentives different from financial (Lievens \& Highhouse, 2003). Increasingly workers look for companies that they perceive can maximize their career potential, increase their skills, provide a satisfying working environment and leave up to their ethical standards (Chowdhury, 2003). Being able to create this perception means creating an environment that first and foremost conveys a coherent identity, that emanates trust and above all an environment that makes its employees proud. An employee who is proud of his or her work and the performance that his or her company can achieve, who feels that he or she is part of a group within which he can be and express himself, certainly has every intention of remaining in the company for as long as possible and continue to contribute to its success. On the other hand, a company that is capable of doing this and that makes its employees so proud, also has a high chance of attracting new talent. Thus, the challenge of HR managers today is to put in place long-term company strategies that make their company being perceived as an attractive place to work.

\subsection{Employer Branding for Attracting Talents}

The most popular framework used by companies in order to establish long term strategies to attract, select and retain the most competent workers is known as Employer Branding (EB). Despite the recent application of this phenomenon, its birth can be traced back when Tim Ambler and Simon Barrow first coined it as a way of combining branding techniques with human resource practices (Ambler \& Barrow, 1996). Kotler (2001) defines a brand as "a name, term, sign, symbol, or design, or a combination of them which is intended to identify the goods and services of one seller or group of sellers and to differentiate them from those of competitors" (p.719). The definition has primarily been used to describe product brands and the consumer's relationship toward the brand (Mosley, 2007). However, according to the current marketing literature, a brand has a positive impact on the company as an employer as it allows external stakeholders to identify the organization, the corporate brand and the firm as a future workplace (Gaddam, 2008).

Before the concept of employer branding was created, Kotler (1994) contributed to the current understanding of the concept of employer branding using the term internal marketing to describe the task of successfully hiring, training and motivating employees to serve the customer well. By satisfying employee's needs, their motivation increases as well as their involvement and commitment towards the company. For instance, companies started 
realising that employees should be considered a tool to differentiate an employer among the competition in order to attract highly skilled labor (Kotler, 1994). Thus, branding and EB are closely related, as what characterizes a strong brand is mostly consistent with successful employer brands (Öster \& Jonze, 2013). Accordingly, Branham (2000) defines employer branding as the practice of "applying traditional marketing principles to achieving the status of Employer of Choice [...], the process of placing an image of being a great place to work in the mind of the targeted candidate pool" (Branham, 2000, p.18). Soon, Backhaus and Tikoo (2004) build on this definition and define employer branding as the process of building an identifiable and unique employer identity, and the employer brand as a concept of the firm that differentiates it from its competitors. According to Sullivan (2004), employer branding is a strategy to manage stakeholders' awareness, perceptions, opinions, and beliefs with regards to a particular organization. Employer branding represents organizations' efforts to communicate to internal and external audiences what makes it both desirable and different as an employer. (Jenner \& Taylor, 2007). It is concerned with building an image in the minds of the potential employees that the company is a 'great place to work' (Ewing et al., 2002). For this purpose, companies have begun to develop targeted recruitment marketing actions so to create a corporate image consistent with the identity of the company, aimed at attracting and retaining talented resources. In other words, employer branding as a concept summarises the strategies of recruiting marketing aiming at developing an image of the company which is coherent with the company's identity as an ideal working environment (employer of choice). In this way, the company is able to attract and build a loyal relationship with talented employees.

\subsubsection{Factors Influencing the Employer Attractiveness and the Employer Branding Process}

Employer branding is the result of a process in which a firm creates and communicates a convincing "employer value proposition" (Backhaus \& Tikoo, 2004). The "employer value proposition" (EVP) is defined as the full "package of reward features or employment advantages and benefits offered to employees" (Barrow \& Mosley, 2005; Edwards, 2010), which in order to be valuable for the talents must be linked to the central message that is conveyed by the corporate brand (Backhaus \& Tikoo, 2004). The concept of employer branding lies at the intersection between EVP and business objectives, understood as a set of activities aimed at spreading an employer identity that allows to narrow the gap between the desired image (by management) and perceived image (by current or potential employees)" (Lievens et al., 2016). Corporate brand image applied to EB can be defined as the perception of an organization as reflected by the brand association held in employee's memory. Collins \& Stevens (2002) applied this acknowledgement to the employer branding context and defined the employer attractiveness as the result of the "potential applicants' attitudes and perceived attributes about the job or organization" and employer branding as the process of building a unique and attractive image as an employer (Backhaus \& Tikoo, 2004, p. 502).

According to Moroko \& Uncles (2008), future employees create their perception of the employer attractiveness during the recruitment process, based on explicit information from the firm (job description), but also on informal information (recruitment experience), which makes the recruitment process vital for the creation of a strong employer image and the EB strategy. Ambler and Barrow (1996) identified three factors driving employer image, namely functional, economic and psychological. Kucherov \& Zavyalova (2012) extend this list to comprise all the set of qualitative features of the employer image that are attractive to a target audience. These features are described by a totally positive image and an appropriate set of both material (economic) and non-material (psychological and functional) advantages that differentiate a company in the job market. Berthon et al. (2005) developed and validated a multi-item scale to identify and operationalize the dimensions of employer image which in turn influences employer attractiveness. According to these authors, (1) interest value, (2) social value, (3) economic value, (4) development value and (5) cooperation/application value are the five building blocks of the attractiveness of an employer's brand: 1. Interest value assesses attraction to an employer that offers an exciting work environment, with forward-thinking and creativity, and an organization that encompasses innovation and interest in product or services; 2 . Social value which refers to the work environment and relations to other employees; 3.Economic value which relates to economic benefits such as salary, compensation, promotion opportunities, and job security; 4. Development value assesses attraction to employment which supports career-enhancing experience, the possibility for future opportunities and provides recognition; 5. Cooperation value which encompasses the possibility to use what has been learned already, and it identifies an environment that is oriented primarily to satisfy societal needs. Table 1 shows the different dimensions, definitions and items as described by Berthon et al. (2005). 
Table 1. Employer image dimensions

\begin{tabular}{|c|c|c|}
\hline Dimension & Definition & Items \\
\hline Interest value & $\begin{array}{l}\text { "[...] the extent to which an individual is attracted to an employer that provides an } \\
\text { exciting work environment, novel work practices and that makes use of its } \\
\text { employees' creativity to produce high-quality, innovative products and services" }\end{array}$ & $\begin{array}{l}\text { - Working in a challenging work } \\
\text { environment } \\
\text { - Innovative employer - innovative } \\
\text { work practices/disruptive ideas } \\
\text { - The organisation values and makes } \\
\text { use of its creativity } \\
\text { - The organisation provides high } \\
\text { quality products and services } \\
\text { - The organisation provides } \\
\text { innovative products and services }\end{array}$ \\
\hline Social value & $\begin{array}{l}\text { "[...] the extent to which an individual is attracted to an employer that provides a } \\
\text { working environment which is fun, happy, and which provides good collegial } \\
\text { relationships and a team atmosphere" }\end{array}$ & $\begin{array}{l}\text { - A fun work environment } \\
\text { - Have a good relationship with your } \\
\text { superiors } \\
\text { - Have a good relationship with your } \\
\text { colleagues } \\
\text { - Encouraging and collaborative } \\
\text { colleagues } \\
\text { - Good working environment }\end{array}$ \\
\hline $\begin{array}{l}\text { Economic } \\
\text { value }\end{array}$ & $\begin{array}{l}\text { "[...] the extent to which an individual is attracted to an employer that provides an } \\
\text { above-average salary, a compensation package, job security, and opportunities for } \\
\text { promotion" }\end{array}$ & $\begin{array}{l}\text { - Good opportunities for promotion } \\
\text { within the organisation } \\
\text { - Opportunity for inter-departmental } \\
\text { practical experience } \\
\text { - Good working environment } \\
\text { - Above-average base salary } \\
\text { - Job security within the } \\
\text { organization }\end{array}$ \\
\hline $\begin{array}{l}\text { Development } \\
\text { value }\end{array}$ & $\begin{array}{l}\text { "[...] the extent to which an individual is attracted to an employer that provides } \\
\text { recognition, self-worth and confidence, together with a career-enhancing } \\
\text { experience and a springboard to future employment" }\end{array}$ & $\begin{array}{l}\text { - Appreciation of your performance } \\
\text { by management } \\
\text { - A launching pad for future jobs } \\
\text { - Feeling good about yourself as a } \\
\text { result of working for a particular } \\
\text { organisation } \\
\text { - Feeling more confident as a result } \\
\text { of working for a particular } \\
\text { organisation } \\
\text { - Gaining professional experience }\end{array}$ \\
\hline $\begin{array}{l}\text { Cooperation } \\
\text { value }\end{array}$ & $\begin{array}{l}\text { "[...] the extent to which an individual is attracted to an employer that provides an } \\
\text { opportunity for the employee to apply what they have learned and to teach others, } \\
\text { in an environment that is both customer-orientated and humanitarian" }\end{array}$ & $\begin{array}{l}\text { - Humanitarian organization - gives } \\
\text { back to society } \\
\text { - Opportunity to apply what has } \\
\text { been learned in a tertiary institution } \\
\text { - Opportunity to teach others what } \\
\text { you have learned in the work context } \\
\text { - Acceptance and belonging } \\
\text { - The organisation is } \\
\text { customer-oriented }\end{array}$ \\
\hline
\end{tabular}

Note. Employer branding dimensions as identified in Berthon et al. (2005).

Of these factors, interest value and social value capture the psychological benefits, while development value and cooperation value capture the functional benefits. The different factors help build the employer image which then defines the extent to which a person is attracted to an employer (Berthon et al., 2005). EB is thus affected by the employer's notion of attractiveness and can be considered the reflection of the image of an organisation. Figure 1. shows the employer branding framework which summarizes the key factors driving employer attractiveness, as resulting from the literature review. 


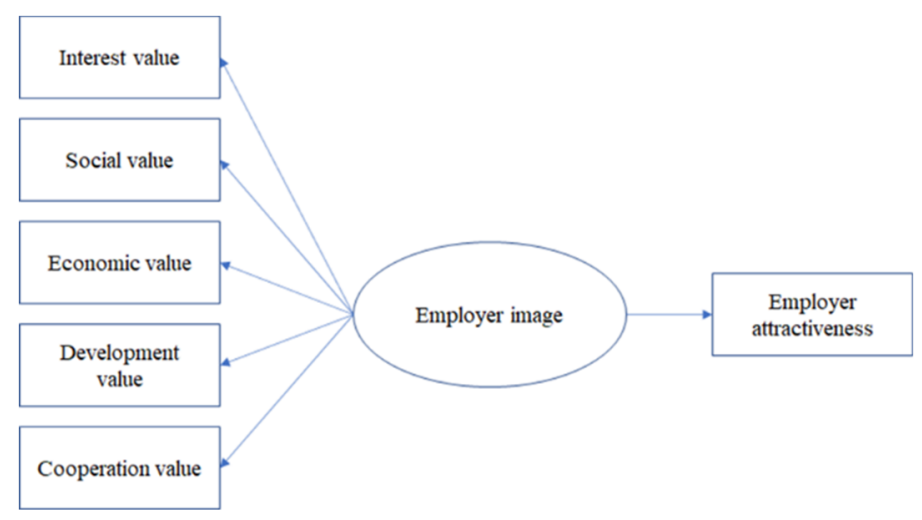

Figure 1. Employer branding framework

\subsection{The Use of Artificial Intelligence to Improve the Employer Image and Employer Attractiveness}

Artificial intelligence (AI) "refers to a field of computer science dedicated to the creation of systems performing tasks that usually require human intelligence. It can be loosely interpreted as incorporation of human intelligence into machines. In AI, machines complete the task based on the stipulated rules and algorithms. AI is an umbrella term for any computer program that has the touch of human intelligence." (Yao et al., 2019, p.15). AI is increasingly used to support decision-making processes in the workplace (Helbing et al., 2019), where algorithms throughout the use of machine learning methods improve decision making processes without requiring the intervention of humans (Günther et al., 2017). The introduction of AI and its application in recruiting has increased the efficiency of the process, marking a profound change within the HR field. AI is currently used to support three general sets of activities of recruitment, namely, outreach, screening, assessment. In the outreach stage, firms aim to identify candidates and promote job opportunities in ways that will push them to apply. AI supports this operation by tailoring the best presentation methods (e.g., banner ads, email, text) for the different target candidates. In other words, the system learns and places job opportunities via banners, popups, email, texts, etc. for the optimal uptake and response by targeting the most suitable candidates' profiles. The second stage requires doing an initial screening, which can be easily done by the AI based on fixed criteria defined by the recruiter (Campbell et al., 2020). Sharma has shown how the use of AI at this stage can help achieve significant reductions for companies in lead time from $60 \%$ to $90 \%$. In addition, not only are firms competitive in the recruiting speed and efficiency that are possible with AI, but also, they potentially generate effective and high-quality services as well. For example, recent research demonstrates that AI-enabled tools outperform at least $25 \%$ in screening applicants compared to high-quality, time-consuming evaluations of humans (Kuncel et al., 2014).

The third stage refers to the use of AI not only in the pre-selection but also for assessment of the candidates. For example, Unilever uses AI-enabled interviews and evaluations to narrow the original pool of over 45,000 candidates for internships in the United States to 300 finalists (Feloni, 2017). During the interview, the AI system asked candidates various questions and candidates submitted their recorded responses. The questions were based on an analysis of successful and average employees in those internship positions in the past. The system analyzed not only the content of candidates' responses but their word choice, tone of voice, and micro facial movements and correlated them to those of the company's successful employees. Candidates were able to participate in the virtual interview on any day or at any time convenient to them within a several-day window. This not only saved countless hours in scheduling but also gave candidates more control over the experience. What makes this third stage particularly relevant for the employer branding process is that at this stage, potential candidates get in contact with the AI tool knowing they are going to be evaluated by it. Ehrhart \& Zieger (2005) have shown how the use of technology in general during the recruitment process has a positive impact on the perceived attractiveness of the employer (Ehrhart \& Zieger, 2005). For instance, extant research reported that organisations prompted to the use of social media were perceived as more attractive by job applicants (Pramod \& Bharathi, 2016), as well as those who actively used social media during the recruiting process (Van Esch et al., 2020). Furthermore, extant research has shown that the use of AI in products and services is correlated with more positive attitudes since people feel high control and accuracy towards the AI products and services (Hamilton \& Davison, 2018). Finally, while extant research has recently criticized the supposed objectivity of AI (Campolo \& Crawford, 2020; Crawford, 2016), showing how AI can also lead to biases, research suggests that AI-enabled 
systems are perceived as less biased and more objective than humans by users (Van Esch et al., 2019).

We can assume that all these factors can play a role in the acceptance of AI-based technology when used for recruiting, and in particular, we can hypothesize that AI-based technology for recruiting can project a positive image of the future employer, as it might be perceived as more objective, accurate, and unbiased, and therefore improve its attractiveness. Therefore, it can be hypothesized that the use of AI might be positively impacting the employer attractiveness and the employer image. We therefore develop the follow hypothesis:

$\mathrm{H} 1$ : The use of AI in the recruitment process has a significant positive impact on the employer attractiveness and on the employer image.

Figure 2 shows the final framework that includes the effect on the use of AI-enabled recruitment, both direct on employer attractiveness and indirect through the impact on the employer image.

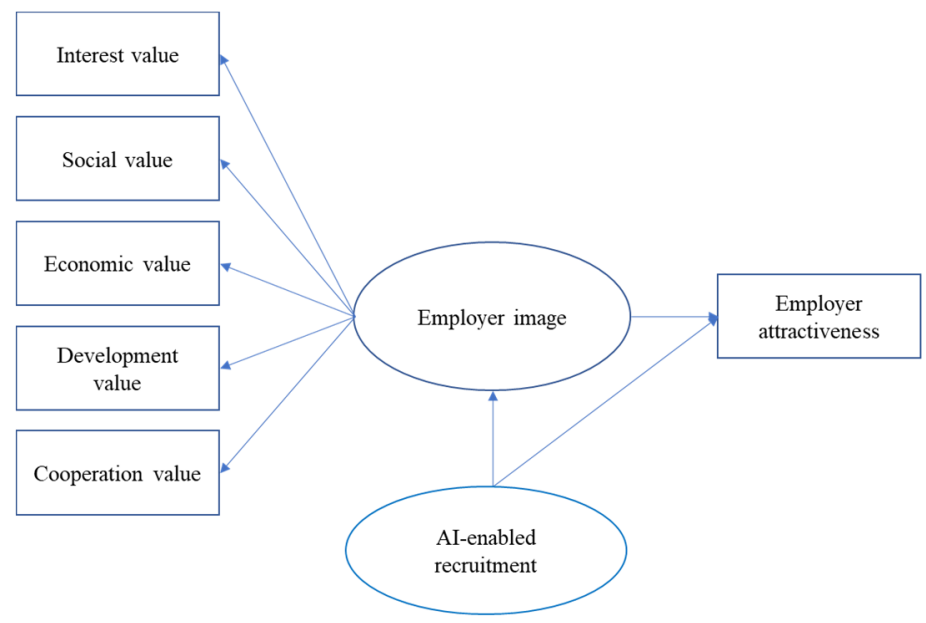

Figure 2. Employer branding framework with AI-enabled recruitment factor

\section{Method}

To assess whether the AI-enabled recruitment process is a relevant factor significantly influencing the employer image and consequently the employer attractiveness, a quantitative analysis has been conducted. In the following paragraphs, we present the data, variables and model used to investigate how people perceive the use of AI in the recruitment process and to test our hypothesis.

\subsection{Data Collection}

This study employs a quantitative research approach by means of a survey to answer the above research questions. The survey was distributed to a sample of the Italian population during October 2019. Respondents were screened so that only those who were in the age range to be potential job candidates were recruited, so that the eligible target is composed of people between 18 and 44 years old. The total number of respondents is 312 , however only 302 fit the validity of the study. The target represents country population distribution of gender for the segment under consideration (18-44) which is $49.7 \%$ men and $50.3 \%$ women. The survey was conducted using computer-assisted web interviewing (CAWI) methodology and the questionnaire was presented online through a web-interface.

\subsection{Measures and Covariates}

In developing the questionnaire's structure and contents, the existing literature has been taken into consideration in order to have a starting point of reference for the selected study. The questionnaire (attached in appendix) comprises 12 questions: closed-ended questions and Likert 7-points-scale response questions. The Likert scale was highly frequently used as a method of likelihood measurement as it allows respondents to choose one option that best aligns with their view and express the extent to which they agree or disagree with a particular question or statement. For instance, a typical scale might be "Strongly disagree, Disagree, Neutral, Agree, Strongly agree." 


\subsubsection{Covariates}

The following variables were used in the analysis:

\section{Employer attractiveness}

The overall employer attractiveness is defined as the willingness to work for a company of the potential candidates, following Luce et al. (2001). Participants were prompted the following question: "How willing would you be to undertake a selection process using artificial intelligence". A 7-point Likert scale ranging from 1 (Completely unwilling) to 7 (Completely willing) was used to measure the degree of willingness.

\section{AI-enabled recruitment factor}

In order to assess the impact that AI-enabled recruitment has on the employer attractiveness and employer image, we developed an ad-hoc battery. The list of items resulted from the literature review and comprises the following items:

- Accuracy is defined as the perceived ability of AI to select the best curricula in relation to the vacant position (Sharma, 2018).

- Velocity is defined as the perceived ability of AI to provide candidates with a final decision in a short period of time (Sharma, 2018).

- Objectivity is defined as the perceived ability of AI to evaluate candidates only on skills and not on non-verbal communication (Bilic, 2016; Black, Van Esch, 2020).

- Reliability is defined as the perceived ability of AI to guarantee no errors or misinterpretation during the process (Bilic, 2016).

- Unbiasedness is defined as the perceived ability of AI to guarantee a fair interview and evaluation only on the performances of the candidates (Black \& Van Esch, 2020).

We first run a correlation analysis with these five items and a factor analysis to test whether all the items were related and associated to the latent component of the AI-enabled recruitment process. The correlation coefficient showed that the Objectivity item had a general low correlation to the other variables compared to the rest of the variables. Then we ran a factor analysis (extraction method Maximum Likelihood, Oblimin rotation), to test whether all the items were contributing properly to the latent variable and found that the loading of the Objectivity item was below the accepted value of 0.500 . We therefore removed this item and ran the factor analysis with only four items. We found that all the items had high factor loadings on one factor, with Bartlett's test of sphericity significantly p-value significantly smaller than 0.05 and Kaiser-Meyer-Olkin Measure of Sampling Adequacy value around 0.902. The final list of items used in the final model comprises the following: Accuracy, Velocity, Reliability, and Unbiasedness.

\section{Employer image}

In order to capture the overall employer image, a multi-items scale battery was used as developed by Berthon et al. (2005). The battery captures the five dimensions of the employer image, namely (1) interest value, (2) social value, (3) economic value, (4) development value and (5) cooperation/application value. For each dimension, an exploratory factor analysis was carried out with the goal of selecting only the most relevant items. The items were factor analyzed (extraction method Maximum Likelihood, Oblimin rotation), yielding a factorial structure in line with the original studies that developed the scales (i.e., with high factor loadings on one factor), with Bartlett's test of sphericity significantly p-value significantly smaller than 0.05 and Kaiser-Meyer-Olkin Measure of Sampling Adequacy value around .888 .

\subsection{Analytical procedure}

In order to test the Employer branding framework as shown in figure 2, a structural equation model (SEM) analysis was carried out. SEM is a combination of factor analysis and multiple regression and describes statistical relationships between latent and manifest (measured) variables. As Cooley (1978) states, this approach allows to establish the plausibility of a theoretical model and to determine the degree to which the explanatory variables (causes) influence the dependent variable (latent). SEM is an alternative way of testing the consistency of a 'structural' theory through data; in this sense it is primarily a 'confirmatory' rather than an 'exploratory' methodology. This method is preferred by the researcher because it estimates the multiple and interrelated dependence in a single analysis. The variables represented with ovals are latent variables, meaning that they are not directly observed (the variables that have been measured on the subjects) but are inferred from the observed variables (rectangles) in order to explain their behaviour. Some variables are independent (variables from which 
the arrows start) and they influence or determine other variables which are known as dependent (variables that receive the arrows). Additionally, SEM provides numerical estimates for each of the parameters in the model to indicate the strength of the relationships. Thus, in addition to testing the overall theory, SEM allows the researcher to diagnose which observed variables are good indicators of the latent variables as well (MacCallum \& Austin 2000). In the framework proposed, we analyzed second order SEM model, as the employer image is the latent dimension of four latent variables (ie. interest, development, cooperation and AI-enabled recruitment factors) and two variables (ie. social and economic value). In order to apply SEM, we used the R package Lavaan that also visually represents the relationship between variables.

\section{Results}

In order to test whether the AI-enabled recruitment process has an impact on the perceived employer attractiveness, we tested a SEM model as reported in Figure 3.

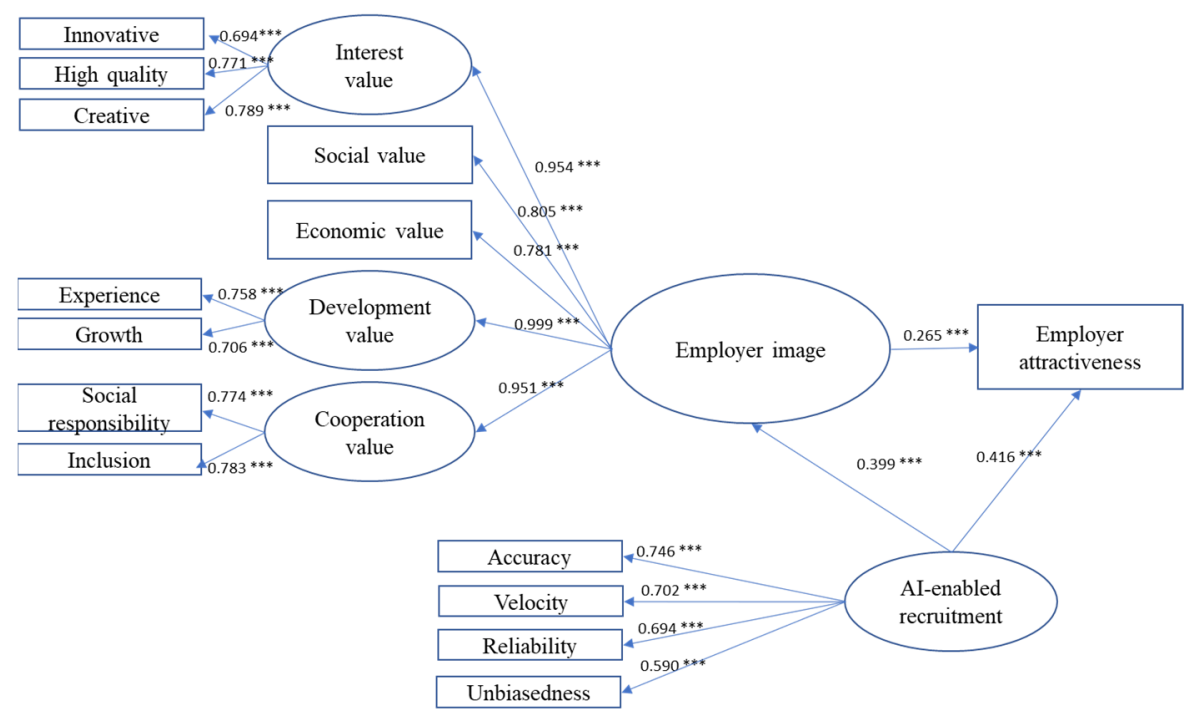

Figure 3. Structural equation modeling results

The overall model shows a good fit. In fact, looking at the comparative fit index (CFI), which compares the fit of a target model to the fit of an independent, or null, model, our model reached a CFI value of 0.933, above the 0.900 which indicates a good model fit. Another index widely used to assess the quality of the model is the root mean square error of approximation (RMSEA), which represents a parsimony-adjusted index. Values closer RMSEA $<=0.08$ represent a good fit. The study fits this value $(0.075)$. Note that all the $p$-values for the parameters estimate are shown and are all $<0.000$, which means highly significant. The AI-enabled recruitment factor is built out of the four dimensions discussed in the methodology section, namely accuracy, velocity, reliability, and unbiasedness. All these dimensions are significant. The dimension contributing most to the AI-enabled recruitment factor is the accuracy $\left(0.746^{* * *}\right)$, meaning that what respondents value most of the AI-enabled recruitment process is the fact that using AI they are confident that they will be selected and positively evaluated if their curricula fit the position. The second dimension is the velocity $(0.702 * * *)$, meaning that the respondents appreciate the fact that using AI in the recruitment process can speed up the whole process. The third dimension is the reliability $\left(0.694^{* * *}\right)$, meaning that they perceived as more objective and reliable the selection made by the AI compared to the human recruiter. Finally, the four dimension is unbiasedness $\left(0.590^{* * *}\right)$, meaning that they perceive the AI as assessing only their performances and skills without being biased by human factors or non-verbal communication that might instead affect the decision of a human recruiter. The model shows also that the dimensions identified in Berthon et al. (2005), are significantly defining the employer image. Among the different dimensions, the most relevant is the development value $(0.999 * * *)$, which captures the perceived image of the employer as offering career enhancing working opportunities. The second dimension is the interest value $(0.954 * * *)$, which captures the perceived image of the employer as offering work in a creative, innovative, and high-quality working environment. The third dimension is the cooperation value $\left(0.951^{* * *}\right)$, which captures the perceived image of the employer as providing a working environment that is 
oriented towards society. The last two dimensions are the social $\left(0.805^{* * *}\right)$ and economic $(0.781 * * *)$ values, which captures the perceived image of the employer as providing a positive working environment to its employees, and good economic benefits, respectively. The two factors of AI-enabled recruitment $\left(0.416^{* * *}\right)$ and employer image significantly and positively associate with the employer attractiveness $\left(0.265^{* * *}\right)$. In particular, the AI-enabled recruitment factor impacts directly on the employer attractiveness, meaning that the higher the recruitment process is driven by the AI, the higher the employer attractiveness. Also, the AI-enabled recruitment factor impacts indirectly through its association with the employer image $(0.399 * * *)$, for a total effect of 0.10 . In fact, the usage of AI in recruitment positively associates with an increase in employer image, which in turn impacts on the employer attractiveness. Based on these findings, we can state that our hypothesis is confirmed: The use of $\mathrm{AI}$ in the recruitment process has a significant positive impact on the employer attractiveness and on the employer image.

\section{Discussion}

The success of a firm increasingly depends on its ability to attract the best talents and successfully engage its employees, as this ability to engage present and future employees is linked to a higher capability in providing value to its customers and it has been found critical to ensure (Colleoni et al., 2021).

This has implied an increased relevance of the recruitment process as strategic tool for competitive advantage and led organisations to introduce increasingly sophisticated technologies for recruiting, such as AI tools in the recruitment process (Pramod \& Bharathi, 2016). While a big portion of the past research on recruiting and selection mainly assessed the reliability and validity of the recruitment and selection process, activities, and techniques (Newell, 2005, Van Esch et al., 2019), there is a lack of research about the candidates' view on AI-enabled recruitment systems and in particular, whether candidates during the recruitment make positive associations with the organization. In order to shed light on whether AI-enabled recruitment indeed is positively associated with employer attractiveness, a quantitative study has been carried out using a survey and an employer branding framework has been developed and empirically validated using SEM modeling.

Results show that AI-enabled recruitment significantly impacts on the perceived employer attractiveness, directly by making the employer be perceived as more accurate, fair, and reliable in the recruitment process, and indirectly, by impacting on the employer image.

All in all, this study presents several implications for organizations. The present research showed a direct and positive relationship between the extent to which candidates perceive the use of AI-enabled technologies during the selection process as a positive factor and the level of organisation's attractiveness. This suggests that moving forward in time organisations may want to highlight, rather than hide, the fact that they use AI-enabled tools during the recruitment process.

This study shows how critical the use of new technologies can be for organizations not only to improve effectiveness in its processes, but also to improve their perception as employers of choice. It is acknowledged that building effective employer branding is a time-consuming process that requires consistency and coherence. However, nowadays, more than ever, attracting the best talents is key for a company's success and this process can be supported with the introduction of AI-enabled recruitment processes. Indeed, the findings of this research highlight the fact that AI provides promising solutions for organizations that aim to win the war for talents by shaping the perception of candidates appearing as employers of choice.

\section{References}

Ambler, T., \& Barrow, S. (1996). The employer brand. Journal of Brand Management, 4(3), 185-206. https://doi.org/10.1057/bm.1996.42

Backhaus, K., \& Tikoo, S. (2004). Conceptualizing and Researching Employer Branding. Career Development International, 9(5), 490-517. https://doi.org/10.1108/13620430410550754

Barrow, S., \& Mosley, R. (2011). The employer brand: Bringing the best of brand management to people at work. John Wiley and Sons.

Beechler, S., \& Woodward, I. C. (2009). The global "war for talent”. Journal of international management, 15(3), 273-285. https://doi.org/10.1016/j.intman.2009.01.002

Berthon, P., Ewing, M., \& Hah, L.L. (2005). Captivating company: dimensions of attractiveness in employer branding. International Journal of Advertising, $151-172$. https://doi.org/10.1080/02650487.2005.11072912

Bilić, P. (2016). Search algorithms, hidden labour and information control. Big Data \& Society, 3(1). 
https://doi.org/10.1177/2053951716652159

Black, J. S., \& van Esch, P. (2020). AI-enabled recruiting: What is it and how should a manager use it? Business Horizons, 63(2), 215-226. https://doi.org/10.1016/j.bushor.2019.12.001

Branham, L. (2000). Keeping the People Who Keep You in Business (p.18). New York: AMACOM.

Campbell, C., Sands, S., Ferraro, C., Tsao, J., \& Mavrommatis, A. (2020). From data to action: How marketers can leverage AI. Business Horizons, 63(2), 227-243. https://doi.org/10.1016/j.bushor.2019.12.002

Campolo, A., \& Crawford, K. (2020). Enchanted determinism: Power without responsibility in artificial intelligence. Engaging Science, Technology, and Society, (6), 1-19. https://doi.org/10.17351/ests2020.277

Chambers, E. G., Foulon, M., Handfield-Jones, H., Hankin, S. M., \& Michaels III, E. G. (1998). The war for talent. The McKinsey Quarterly, (3), 44.

Colleoni, E., Bonaiuto, F., Illia, L. \& Bonaiuto, M. (2021) Computer-assisted concept analysis of Customer Centricity: A review of the literature on employee engagement, culture, leadership, and identity co-creation. Sustainability, 13(9), 5157. https://doi.org/10.3390/su13095157

Collins, C. J., \& Stevens, C. K. (2002). The relationship between early recruitment-related activities and the application decisions of new labor-market entrants: a brand equity approach to recruitment. Journal of Applied Psychology, 87(6), 1121-1133. https://doi.org/10.1037/0021-9010.87.6.1121

Cooley, W. W. (1978). Explanatory observational studies. Educational Researcher, 7(9), 9-15. https://doi.org/10.3102/0013189X007009009

Crawford, K. (2016). Can an algorithm be agonistic? Ten scenes from life in calculated publics. Science, Technology \& Human Values, 41(1), 77-92. https://doi.org/10.1177/0162243915589635

Edwards, M. R. (2010). An integrative review of employer branding and OB theory. Personnel Review, 39, 5-23. https://doi.org/10.1108/00483481011012809

Ehrhart, K. H., \& Ziegert, J. C. (2005). Why are individuals attracted to organizations? Journal of management, 31(6), 901-919. https://doi.org/10.1177/0149206305279759

Ewing, M. T., Leyland, F. P., Nigel, M., \& Pierre, B. (2002). Employment branding in the knowledge economy. International Journal of Advertising, 21, 3-22. https://doi.org/10.1080/02650487.2002.11104914

Feloni, R. (2017). Consumer-good giant Unilever has been hiring employees using grain games and artificial intelligence and it's a huge success. Business Insider Australia.

Gaddam, S. (2008) Modeling Employer Branding Communication: The Softer Aspect of HR Marketing Management. The Icfai Journal of Soft Skills, 2(1), 45-55.

Gray, E. R., \& Balmer, J. M. (1998). Managing corporate image and corporate reputation. Long range planning, 31(5), 695-702. https://doi.org/10.1016/S0024-6301(98)00074-0

Günther, W. A., Mehrizi, M. H. R., \& Huysman, M. (2017). Debating Big Data: A Literature Review on Realizing Value from Big Data. The Journal of Strategic Information Systems, 26(3), 191-209. https://doi.org/10.1016/j.jsis.2017.07.003

Helbing, D. (2019). Towards digital enlightment. Springer, Germany. https://doi.org/10.1007/978-3-319-90869-4

Jenner, S., \& Taylor, S. (2007), Employer branding-fad or the future of HR? in CIPD, London. Retrieved from http://www.cipd.co.uk/NR/rdonlyres/56C8377F-256B-4556-8650-8408B0E07576/0/empbrandlatfad.pdf

Johnson, B., Manyika, J., \& Yee, L. (2005). The next revolution in interactions. McKinsey Quarterly, 4, 20-33.

Kaplan, R. S., Kaplan, R. E., Norton, D. P., Davenport, T. H., \& Norton, D. P. (2004). Strategy maps: Converting intangible assets into tangible outcomes. Harvard Business Press: Boston, MA.

Kotler P. (1994). Marketing Management: Analysis, Planning, Implementation, and Control (8th ed.). Prentice Hall: Englewood Cliffs, NJ.

Kotler, P. (2001). Marketing Management (10th ed.). Praha: Grada Publishing.

Kucherov, D., \& Zavyalova, E. (2012). HRD practices and talent management in the companies with the employer brand. European Journal of Training and Development, 36(1), 86-104. https://doi.org/10.1108/03090591211192647

Kuncel, N. R., Klieger, D. M., \& Ones, D. S. (2014). Hiring, algorithms beat instinct. Harvard Business Review, 
92(5), 32 .

Landers, R. N. (2019). The Cambridge handbook of technology and employee behavior. Cambridge University Press: Cambridge, UK. https://doi.org/10.1017/9781108649636

Lievens, F., \& Highhouse, S. (2003). The relation of instrumental and symbolic attributes to a company's attractiveness as an employer. Personnel Psychology, 56, 75-102. https://doi.org/10.1111/j.1744-6570.2003.tb00144.x

Lievens, F., \& Slaughter, J. (2016). Employer Image and Employer Branding: What We Know and What We Need to Know. Annual Review of Organizational Psychology and Organizational Behavior, 3. https://doi.org/10.1146/annurev-orgpsych-041015-062501

Luce, M. F., Bettman, J. R., \& Payne, J. W. (2001). Emotional decisions: Tradeoff difficulty and coping in consumer choice. Monographs of the Journal of Consumer Research, (1), 1-209.

MacCallum, R., \& Austin, J. (2000). Applications of Structural Equation Modeling in Psychological Research. Annual Review of Psychology, 51, 201-226. https://doi.org/10.1146/annurev.psych.51.1.201

Michaels, E., Handfield-Jones, H., \& Axelrod, B. (2001). The war for talent. Boston, MA: Harvard Business School Press.

Moroko, L., \& Uncles, M. D. (2008). Characteristics of successful employer brands. The Journal of brand management, 16(3), 160-175. https://doi.org/10.1057/bm.2008.4

Mosley, R. W. (2007). Customer experience, organisational culture and the employer brand. Journal of brand management, 15(2), 123-134. https://doi.org/10.1057/palgrave.bm.2550124

Newell, S. (2005). Recruitment and selection. Managing human resources: Personnel management in transition, 115-147.

Oracle. (2019). State of Artificial Intelligence in Talent Acquisition. Retrieved from https://www.oracle.com/a/ocom/docs/artificial-intelligence-in-talent-acquisition.pdf

Öster, H., \& Jonze, J. (2013). Employer branding in human resource management: The importance of recruiting and retaining employees. Retrieved from https://www.diva-portal.org/smash/record.jsf?pid=diva2\%3A603822\&dswid=-4570

Pramod, D., \& Bharathi, S. V. (2016). Social media impact on the recruitment and selection process in the information technology industry. International Journal of Human Capital and Information Technology Professionals (IJHCITP), 7(2), 36-52. https://doi.org/10.4018/IJHCITP.2016040103

Sharma, A. (2018). How AI reinvented hiring practice at L'Oreal. People Matters. Retrieved from https://www.peoplematters.in/article/techhr-2018/how-the-worldslargest-cosmetic-company-transformed-its -hiring-practicewith-ai-19006

Sullivan, J. (2004). Eight Elements of a Successful Employment Brand, ER Daily. Retrieved from http://www.ere.net/2004/02/23/the-8-elements-of-a-successfulemployment- Brand

Sutherland, M. M., Torricelli, D. G., \& Karg, R. F. (2002). Employer-of-choice branding for knowledge workers. South African Journal of Business Management, 33(4), 13-20. https://doi.org/10.4102/sajbm.v33i4.707

Van Esch, P., Black, J. S., \& Arli, D. (2020). Job candidates' reactions to AI-Enabled job application processes. AI and Ethics, 1-12. https://doi.org/10.1007/s43681-020-00025-0

Van Esch, P., Black, J. S., \& Ferolie, J. (2019). Marketing AI recruitment: The next phase in job application and selection. Computers in Human Behavior, 90, 215-222. https://doi.org/10.1016/j.chb.2018.09.009

Williams, M. (2000). The war for talent: Getting the best from the best. London, UK: Chartered Institute of Personnel and Development (CIPD).

Yao, M., Sohul, M., Marojevic, V., \& Reed, J. H. (2019). Artificial intelligence defined 5G radio access networks. IEEE Communications Magazine, 57(3), 14-20. https://doi.org/10.1109/MCOM.2019.1800629

\section{Copyrights}

Copyright for this article is retained by the author(s), with first publication rights granted to the journal.

This is an open-access article distributed under the terms and conditions of the Creative Commons Attribution license (http://creativecommons.org/licenses/by/4.0/). 